\title{
An up-to-date view of the evolution of Memórias do Instituto Oswaldo Cruz from 1907 to 2006
}

The journal Memórias do Instituto Oswaldo Cruz was created by Decree No. 1812, of December 12, 1907, when the Manguinhos Experimental Pathology Institute (Instituto de Patologia Experimental de Manguinhos) was founded. Article 1, paragraph 9, of this decree determined that studies originating from the Manguinhos Institute would be published by ways of annals ("memórias"), as the experiments were confirmed. Memórias would be distributed among the professional schools of medicine, veterinary science, and agriculture that existed in the country, and would have exchanges with foreign publications of the same type.

Memórias was initially a typically institutional journal, in that it performed the role of an archive for scientific production from the institution that edited it. Thus, in 1923, the information was given just after the contents list that Memórias would be exclusively reserved for the publication of original work carried out at the Institute.

Since there was no one at the Institute who could take care of setting the journal up, Oswaldo Cruz took on all the work himself. He had the responsibilities of choosing the printing presses, selecting the typeface, ordering the paper, reaching understandings with lithographers and specialists in stereotype plates, selecting translators and reviewing the proofs. When, for any reason, he had to be absent, he passed the task over to Adolpho Lutz, who equally distinguished himself with regard to the journal's quality. Oswaldo Cruz's personal involvement was also underscored in the regulation that determined that studies could only be published in the name and under the responsibility of the Institute if they had been approved by the director.

To meet the quality criteria demanded by the journal's regulations, the Institute installed its own printing press, on which Memórias was printed from 1909 to 1940. In 1940, by decree, the National Press became responsible for carrying out all the printing work for federal government departments.

The first issue of volume I was published in April 1909, in which each article had a text in Portuguese and another in French, English or German, according to the author's wishes, in order to make the articles accessible to foreign readers who did not know our language. In the second issue, the article Nova tripanozomiaze humana, by Carlos Chagas, was published with a translation into German.

Memórias was initially published as one volume per year, with a possible range of one to five issues per volume. Breaking the sequence of one volume per year, two volumes per year were published in 1922, 1930, 1934, 1943,1944 , and 1945 . In 1996, publication of six issues per volume started.

The first supplement for Memórias dates from 1928/ 1929 and contained a variety of studies without, how- ever, demonstrating a relationship with events of any nature. Without such justifications, the publication of supplements was halted and resumed in 1984, always connected with a given scientific event. Examples that can be cited include symposia in homage to Carlos Chagas, Hugo de Souza Lopes, and Lauro Travassos and symposia on malaria, immunomodulators, insects, pests and vectors, pharmacology and natural products, extracellular matrix, eosinophilia, nitric oxide, paleoparasitology and paleopathology, among others. Furthermore, there were the supplements that reproduced the annual meetings on basic research relating to Chagas disease, from 1986 to 2000, and the international symposia on schistosomiasis, of which the tenth was published this year.

Whereas initially Memórias exclusively published studies originating from the Institute, in 1956 the adverb "exclusively" was replaced by "principally". In 1959 it was made explicit that the journal was destined for publication of original research produced by members of the Institute's scientific staff, which exceptionally could include collaboration by authors from outside the Institute.

In 1980, now in its modern phase, Memórias started to publish studies from other national and foreign institutions, under the condition that these should be original, of a good level and be guided by the journal's publication standards.

It was at this time that the journal came to have the figure of the Editor, since up to that point this role had been performed in different manners: from 1909 to 1959, all the indications are that it had a director; from 1959 to 1964 it had an editor-secretary for publications; from 1965 to 1975 there was an editorial committee composed of two to five researchers; in 1976 the position became one of "editorial consultancy"; in 1980 the title of editor emerged, which until 1985 was a function of the Director of the Institute, who started to have the collaboration of an Editorial Board; and from 1986 onwards, the position of editor started to be occupied by an independent researcher, a policy that has continued until today.

I had the honor of becoming the first official Editor of Memórias do Instituto Oswaldo Cruz, when in January 1980 , as the Director of our Institute, I took on this position cumulatively, so that we could resurrect the journal, which had not been published for three years (19771979). From January 1980 to December 2006 the following researchers were the editors of Memórias do Instituto Oswaldo Cruz:

- José Rodrigues Coura - January 1980/December 1985

- Leonidas de Mello Deane - January 1986/March 1989

- Eloi de Souza Garcia - April 1989/June 1993

- Hooman Momen - July 1993/July 2001

- José Rodrigues Coura - August 2001/December 2006 
In January 1986, I handed over Memórias in a fully recovered condition, with an active Editorial Board and a functioning Administrative Secretariat, to the new editor, Dr Leonidas de Mello Deane, who maintained and improved the journal's quality, assisted by Associate Editors and, from 1988 onwards, by the Administrative Editor Mrs Marly de Carvalho Willcox, who had already acted as Head of the Secretariat of Memórias since 1980. In April 1989, Dr Eloi de Souza Garcia took over the position of Editor and implemented an important step for the journal by publishing it in English from 1986 onwards, and having it indexed in Institute for Scientific Information from 1990 onwards. From July 1993 to July 2001, Dr Hooman Momem, took over the position of Editor and definitively modernized the journal and increased its activity to eight regular issues per year and two supplements. The journal was placed online from 1997 onwards, and its impact factor started to rise from that time onwards, as can be seen in the Table and Figure bellow. During this period the Administrative Editorship was taken over by Luciane de Carvalho Willcox, from January 1997 onwards, in replacement for Marly, who had retired.

In August 2001, upon recommendation from Dr Momen and invitation from the new Director of Instituto Oswaldo Cruz, Dr Renato Sergio Balão Cordeiro, I again took over the position of Editor of Memórias, which has continued over the last two years (2005 and 2006)

Memórias do Instituto Oswaldo Cruz Total citations and impact factor - 1994/2005

\begin{tabular}{ccc}
\hline Year & Total citations & Impact factor \\
\hline 1994 & 524 & 0.255 \\
1995 & 538 & 0.306 \\
1996 & 680 & 0.314 \\
1997 & 797 & 0.440 \\
1998 & 937 & 0.474 \\
1999 & 1.281 & 0.636 \\
2000 & 1.299 & 0.542 \\
2001 & 1.443 & 0.643 \\
2002 & 1.714 & 0635 \\
2003 & 1.805 & 0.688 \\
2004 & 1.928 & 0.740 \\
2005 & 2.284 & 0.847 \\
\hline
\end{tabular}

Source: Journal Citation Reports (JCR), Institute of Scientific Informations (ISI).

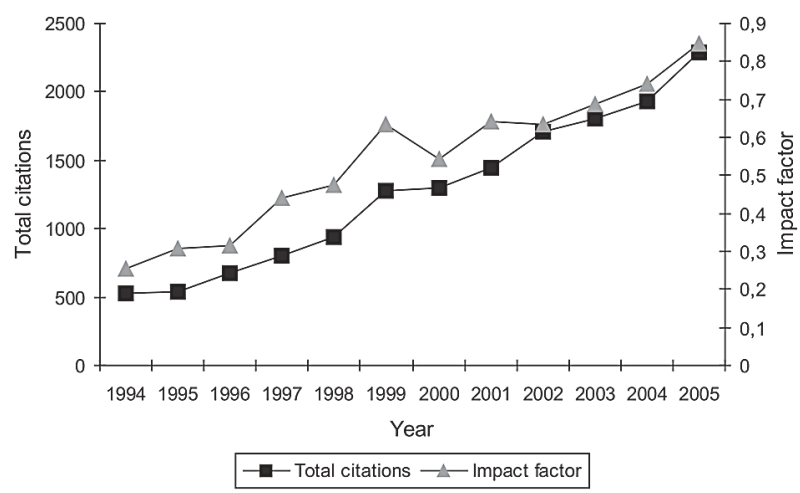

into the administration of the Director Dr Tânia Cremonini de Araújo-Jorge. At their invitation, I once again faced this magnificent and emotive task of being the Editor of Memórias do Instituto Oswaldo Cruz, which is only comparable to having been the Director of this Institute twice, totalling ten years. In Memórias, for which I have been the Editor for ten years and five months, initially during its recovery phase from January 1980 to December 1985, and at its apogee from August 2001 to December 2006, I have left the best of my life. I am leaving the Scientific Editorialship of Memórias for absolutely personal reasons: the desire to dedicate the last years of my academic life to what I most like to do - to research, study, teach and live.

Upon concluding its 101st volume now, in December 2006, I will be leaving Memórias at its apogee, with a rising impact factor, with an average of 540,000 accesses to its web site per month, according to Bioline International, with recognized prestige within the national and international scientific community and, finally, with all its issues from 1909 to 2006 digitized and online, which will give the journal total visibility.

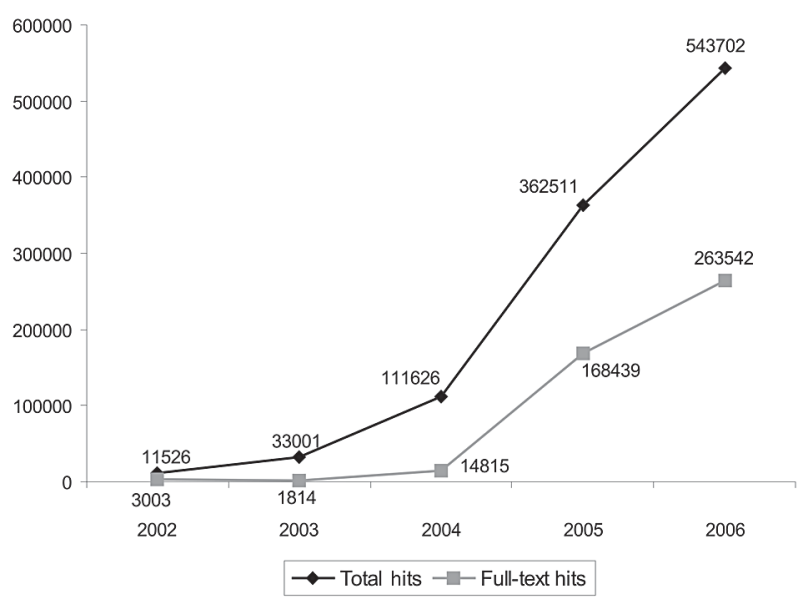

Source: Bioline International

\section{REFERENCES}

Coura JR, Ferreira LF, Paraense WL 2000. Memórias do Instituto Oswaldo Cruz. In Centenário do Instituto Oswaldo Cruz, p. 713-716.

Coura JR, Willcox LCB 2003. Impact Factor, Scientific Production and Quality of Brazilian Medical Journals. Mem Inst Oswaldo Cruz 98: 1-4.

Coura JR, Willcox LCB 2005. Impact Factor Evolution on Memórias Instituto Oswaldo Cruz. Mem Inst Oswaldo Cruz 100: 457-458.

Coura JR, Willcox LCB 2006. Memórias do Instituto Oswaldo Cruz: tradition and inovation. Mem Inst Oswaldo Cruz 101: 1 .

Willcox MC 1989. Memórias do Instituto Oswaldo Cruz. 80 anos de editoração. Mem Inst Oswaldo Cruz 84: 435-439.

Rio de Janeiro, December 2006 José Rodrigues Coura 